\title{
VÁMSZABAD TERÜLETEK ÉS TÉRSZERVEZŐ SZEREPÜK MAGYARORSZÁGON
}

\author{
(Customs-free Zones and Their Space-organising Role \\ in Hungary)
}

\section{VOLTER EDINA}

\section{Bevezetés}

Magyarországon a piacgazdasági átmenet időszakában a területfejlesztés széles körủ eszközrendszere került kidolgozásra és alkalmazásra az ország különböző adottságú térségeiben a társadalom és a gazdaság megújulását elősegítő, a térségi erőforrásokat hasznosító fejlesztési politika megvalósítása érdekében.

A területfejlesztés közvetlen kormányzati eszközei (egyedi nagyberuházások, az infrastruktúra fejlesztése, egyéb közvetlen állami területfejlesztési beruházások) látványosan előmozdíthatják egy adott térség (régió, megye, kistérség) fejlődését, felzárkóztatását. A rendszerváltás óta eltelt időszakban ezen eszközrendszer alkalmazása a területfejlesztési politikában háttérbe szorult, és előtérbe kerültek a közvetett kormányzati eszközök. Így, pl. adókedvezmények nyújtása, vissza nem térítendő támogatások, hitelkamat támogatás, hitelgarancia nyújtás, gyorsított amortizáció, vámkedvezmények nyújtása stb.

Az 1990-es években (és különösen annak második felében, amikor kiépült a területfejlesztés intézményrendszere) a hangsúly, a figyelem a közvetlen pénzuigyi támogatások megszerzésére és felhasználására irányult, és kevésbé került előtérbe az állam területfejlesztésben betöltött szerepe és a regionális fejlödésre gyakorolt hatása az adókedvezmények, még kevésbé a vámkedvezmények nyújtása által. A kijelölt térségekben a beruházások közterheinek (adók, illetékek, vámok stb.) részleges vagy teljes mértékủ elengedése gyakran alkalmazott gazdasági eszköz a fejlesztések támogatására. Ezeket a legfejlettebb piacgazdaságok is elöszeretettel alkalmazzák. Előnyük az állam szempontjából az, hogy az állam nem előlegezi meg a költségeket, és nem vállal anyagi kötelezettséget, hanem csak lemond esetleges bevételeiröl. Vagyis olyasvalamiről mond le, ami az esetek egy részében egyébként sem lenne az övé, mert a fejlesztésekre nem kerül sor (Bartke 1995).

Magyarországon már több mint két évtizede lehetőség nyílik arra, hogy gazdasági társaságok az ún. vámszabad területeken vámkedvezményeket vehessenek igénybe. Tanulmányunkban e területeket mint területfejlesztési és gazdaságpolitikai eszközöket kívánjuk bemutatni, hangsúlyozva funkcionális tagoltságukat, térszervező szerepüket és nemzetgazdasági jelentőségüket. 


\section{A vámszabad terïletek és típusaik}

A vámszabad terület egy adott ország olyan elkülönített részét jelenti, ahol a külföldről raktározás, ehhez kapcsolódó más szolgáltatás ill. ipari feldolgozás céljából ide beszállitott vámárut meghatározatlan időre (az itteni tartózkodás idejére) mentesítik a vám, esetleg más, a vámhoz kapcsolódó illetékek, adók megfizetése alól ${ }^{1}$. Magyarországon a vámjogról, a vámeljárásról valamint a vámigazgatásról szóló 1995. évi C. törvény hatályos rendelkezései a vámszabad területek két típusát, a raktározási és az ipari célú vámszabad területeket ${ }^{2}$ különböztetik meg.

Raktározási célú vámszabad területen külföldröl származó vámáru tárolható, ideiglenes jelleggel, harmadik országba vagy a származási országba történő továbbszállításig. Ennek megfelelỏen vámszabad raktárba (amely az új neve a korábbi kereskedelmi vámszabad területnek) csak közvetlenül külföldröl lehet vámárut beszállítani.

Ipari vámszabad terïlet létesítése akkor engedélyezhető hazánkban, ha ott import anyagok és alkatrészek felhasználásával történö exportcélú termelési tevékenységet végeznek. Termelési tevékenységnek tekinthetö:

a) az áruval kapcsolatos minden olyan müvelet, amelynek eredményeként a termék statisztikai termékosztályozási besorolási száma megváltozik, vagy

b) a bérmunkaszerzödés alapján végzett tevékenység, valamint

c) az alaptevékenységhez kapcsolódó raktározás.

\section{Raktározási vámszabad területek}

Magyarországon a II. világháborút követően csupán a Csepel-szigeten, a MAHART Nemzeti Szabadkikötő területén létesült vámszabad terület 1958 júliusában. További vámszabad területek létesítése csak 1979. évtől vált lehetségessé. Elöször a MASPED szállítmányozói raktárában, valamint a Közraktározási Vállalat hét közraktárában (Baja, Györ, Miskolc, Szabadbattyán, Szajol, Pécs, Budapest) létesült vámszabad terület. Ezt követték a Soproni GYSEV, TRANSPACK Kimle, DEPO Törökbálint, MALÉV Ferihegy vámszabad területek. Ezeken a területeken alapvetően raktározás, illetve ezzel összefüggésben más szolgáltató tevékenység (osztályozás, átcsomagolás stb.) történt külföldi megbízás alapján. A vámszabad területre történő beraktározás (legyen szó akár külföldi, akár magyar eredetủ áruról) csak külföldi természetes vagy jogi személy megbízása alapján történhetett. Ennek következtében a raktározással illetve a végzett szolgáltatással kapcsolatos díjak kiegyenlítése is csak külföldi (konvertibilis) fizetőeszközzel volt lehetséges (Ruttkay 1994).

A raktározási vámszabad területek száma 1993-ban már meghaladta a százat (102), melyek 46\%-a Budapesten és Pest megyében müködött. Az 1995. évi vámtörvény életbelépését követően azonban számuk drasztikusan visszaesett: 1995-ben még 91 raktározási célú vámszabad terület müködött Magyarországon, 1997-ben és 1998-ban viszont már csak nyolc. 
A visszaesés oka, hogy a vámtörvény rendelkezése szerint a raktározási célú vámszabad területen külföldről származó vámáru tárolható, ideiglenes jelleggel, harmadik országba vagy a származási országba történő továbbszállításig. Ez azt jelenti, hogy a raktározási célú vámszabad területre csak közvetlenül külföldről (a vámhatáron külföldről) lehet vámárut beszállítani, és csak a tényleges vámhatáron kívülre lehet azt kiszállítani. E rendelkezés szerint megszünt a raktározási célú vámszabad területnek a belfölddel fenntartott kapcsolata. Ilyen elörás mellett a raktározási célú vámszabad területet üzemeltetők indokolatlannak tartották a további múködtetést, és többségük köz- illetve magánvámraktárrá nyilváníttatta a korábban kereskedelmi vámszabad területként müködtetett raktáraikat (Buzási 1999).

A raktározási célú vámszabad területek száma a fentebb leírt változások következtében az elmúlt évben is tovább csökkent. 2000 első negyedévében négy vállalkozás múködtetett ilyen területet Magyarországon, melyek a Kelet-Európa felé értékesíteni kívánt, illetve onnan érkező termékeket magyarországi vámszabad területen bérraktározzák, abból a célból, hogy megrendelés esetén rövid időn belül leszállíthassák az árut. Ezen gazdasági szervezetek: TÉKISZ Kereskedelmi, Szolgáltató és Szállítmányozási Rt. (Tuzsér), IKR Termelésfejlesztési és Kereskedelmi Rt. (Nagyigmánd), AGROTRANS Termékforgalmazó és Feldolgozó Kft. (Nagykanizsa) és LEONI HUNGÁRIA Ipari és Kereskedelmi Kft. (Eger).

\section{Ipari vámszabad területek}

Az 1980-as évek elején a külföldi mủködőtőke-bevonás ösztönzése érdekében a Pénzügyminisztérium Nemzetközi Főosztályán vetődött fel az ipari vámszabad területek létrehozásának ötlete. Kiindulásuk az volt, hogy a kötött devizagazdálkodási rendszer, az importengedélyezési rezsim, a magas vámok és a nehézkes vámkezelési rendszer olyan kötöttségek, amelyek megakadályozzák a külföldiek befektetéseit. A törvényi szabályozás 1982 óta teszi lehetövé ipari vámszabad területek létrehozását Magyarországon, az első ilyen típusú vámszabad területet azonban csak 1986-ban hozták létre.

Az 1980-as évek végén az ipari vámszabad területek száma jelentősen megnövekedett, a külföldiek magyarországi befektetéseiröl szóló 1988. évi XXIV. törvény ugyanis lehetôvé tette, hogy kizárólag külföldi tulajdonú vállalatot is lehessen alapítani vámszabad területen ${ }^{3}$. Ezt követöen egyre több tőkeerös és exportorientált külföldi befektető, fơként multinacionális vállalat alapított ipari vámszabad területet Magyarországon, elsősorban a nyugati határszélen illetve a Dunántúlon. Míg a raktározási vámszabad területek száma az 1990-es évek második felére drasztikusan lecsökkent, az ipari vámszabad területek száma tovább növekedett. 1993-ban 85 ilyen típusú terület müködött hazánkban, 2000 első negyedévének végén pedig már 125 . 
Ha e két évben összehasonlítjuk az ipari vámszabad területek földrajzi elhelyezkedését regionális szinten, a vizsgálatból az alábbi következtetések vonhatók le (1. ábra):

- 1993-ban az ipari vámszabad területek 37\%-a a Közép-magyarországi régióban volt található, 2000-ben már csak 12\%-a. A fövárosban jelenleg öt vámszabad terület múködik.

- Ezzel ellentétes folyamat zajlott le a három dunántúli régióban, ahol a vámszabad övezetek száma több mint kétszeresére (a Közép-dunántúli régióban háromszorosára) növekedett a vizsgált időszakban. Kimagasló a vámszabad övezetek területi koncentrációja Székesfehérvárott (13 vámszabad terület), Pécsett (8), Sárváron (6) és Győrben (6).

- A növekedés dinamikája az Észak-magyarországi régióban a középdunántúliét is meghaladta, ami pozitív eredményként értékelhető, hiszen az észak-magyarországi országrész 1993-ban még az utolsó helyen állt a régiók rangsorában. A vámszabad területek régión belüli elhelyezkedése is kedvező képet mutat, mivelhogy olyan településeken is létesültek vámszabad területek, ahol az ipar szerkezetátalakítása létfontosságú: Ózd, Kazincbarcika, Miskolc, Sátoraljaújhely.

- Az ipari vámszabad területek térszervező szerepüket legkevésbé az Alföld iparának strukturális átalakítására gyakorolták a piacgazdasági átmenet időszakában, ami összefüggésben áll a külföldi múködőtőke-bevonás alacsony szintjével. Az Alföldön a vámszabad területi társaságok közel 50\%-a Kecskeméten folytat ipari termelést, ugyanakkor Jász-Nagykun-Szolnok és Békés megyében nem múködik egyetlen vámszabad terület sem.

\section{1. ÁBRA}

Az ipari vámszabad területek tervezési-statisztikai régiónkénti megoszlása (\%) (The Distribution of Industrial Customs-free Zones by Planning-Statistical

\section{Regions)}

1993

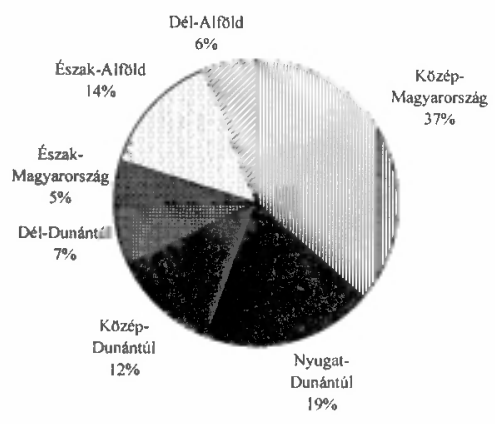

2000

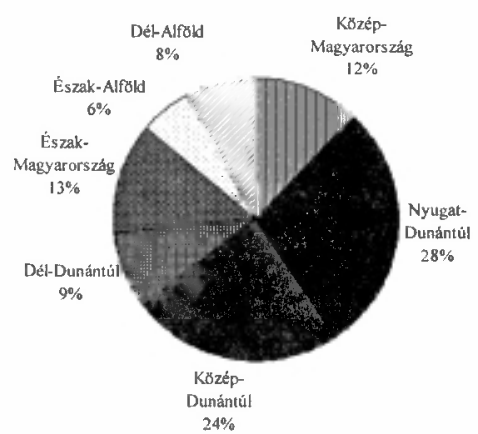

Forras: Béda 1993, 45-47; VPOP. 
A Magyarországon termelő tevékenységet folytató 125 vámszabad területet 101 vállalat mủködteti, ami azzal magyarázható, hogy hazánkban egy vámszabad területi társaság valamennyi tevékenységére - bizonyos feltételek teljesítése esetén alapíthat vámszabad területet. A legtöbb vámszabad területet a LEAR-csoport müködteti Gödöllőn, Gyöngyösön, Györben és két területet Móron, melyeket a Philips, a Flextronics és a Vogel\&Noot követ egyenként négy vámszabad zónával.

\section{Az ipari vámszabad területi termelés elönyei}

A magyarországi vámszabad övezeteket szinte kivétel nélkül külföldi befektetők alapították, a legnagyobb vámszabad területi cégek pedig $100 \%$-ban külföldi tulajdonban vannak. Az ipari vámszabad területen való müködés elsősorban olyan gazdasági elönyöket eredményez az üzemeltető vállalkozás számára, amelyek növelik a termelés hatékonyságát és versenyképességét. Ezen elönyök:

- A termelöeszközök, felszerelési és berendezési tárgyak vámfizetés nélküli behozatala - ide nem értve az építési anyagokat, épületgépészeti és épületfenntartási tárgyakat.

- Az alapanyagok, alkatrészek, részegységek vámfizetés nélküli behozatala.

- A könyvelés devizában történő vezetése.

A külföldi befektetők számára a legvonzóbb feltételt az jelenti, hogy az üzembe behozott termelö-berendezések után nem kell megfizetniük a vámterheket. Ennek különösen azóta van jelentösége, amióta 1996-ban megszüntetésre került az apport vámmentessége. $\mathrm{A}$ vámszabad területen való müködésnek ezen legnagyobb előnye ráadásul mindjárt a beruházás során realizálódik, tehát még termelni sem kezdett a vállalkozás, máris elönyben van más vámterületi versenytársaival szemben.

Egyelöre nem elhanyagolható az az elöny sem, hogy a késztermékekbe beépülö alapanyagok, alkatrészek, részegységek vám-, áfa-, fogyasztási adó- és környezetvédelmi termék díj fizetés nélkül vihetők be vámszabad területre. Igaz, hogy a nem vámszabad területen termelö vállalkozás is visszaigényelheti a vámterhet, ha exportálja termékét. A vámszabad területi cég előnye, nyeresége viszont a visszaigényelhetö vámterhek - az import és az export közötti időtartamra eső - kamata.

$\mathrm{Az}$ ipari vámszabad területen való müködés további előnyét jelenti, hogy mivel a vámszabad terület devizaszempontból devizakülföldinek minősül, az itt müködő cégek könyvelésüket devizában vezetik, ami által kivédhető például a sorozatos forintleértékelés mérlegrontó hatása. Az árfolyamváltozásokat figyelembe véve a belföldi gazdálkodókkal szemben költségelönyt jelent az is, hogy a munkabéreket forintban fizetik, a költségeket pedig devizában könyvelik (Buzási 1999).

\section{Az ipari vámszabad területek nemzetgazdasági jelentősége}

1994 és 1997 között a vámszabad területi vállalkozások teljesítménymutatói folyó áron számítva rendkívül dinamikusan nőttek: közel megtízszereződtek, s 1997-ben már a GDP 5,1\%-át állították elő. Ugyanezen időszak alatt a vámterületi vállalkozások esetében csak két-, két és félszeres növekedést lehet kimutatni. 
A vámszabad területek meghatározó szerepét a nemzetgazdaságban leginkább a külkereskedelemi adatok tükrözik: a vámszabad területi kivitel aránya az összes exportban az 1996. évi 18\%-ról 1997-ben 26,6, 1998-ban pedig 36\%-ra emelkedett, a behozatalban részesedésük alacsonyabb szintü, de szintén növekvő: 14,0\%, 19,1\% és $25 \%$ volt ugyanezen években ${ }^{4}$. Szerepük a foglalkoztatásban háttérbe szorul, 1997-ben az összes foglalkoztatottak nem egészen 1\%-ának biztosítottak munkalehetőséget, melynek hátterében a gépi beruházások magas foka áll.

Az elmúlt évben Magyarországon müködő ipari vámszabad területek 71\%-án gépipari termelés folyt, 40 vámszabad terület híradástechnikai, elektronikai, számítástechnikai részegységek, alkatrészek, késztermékek gyártását végezte, 22 autóipari alkatrészek, 18 gépek termelésére szakosodott; 14 terület, az összes övezet 12\%-a pedig textil- és ruházati termékek elóállítására szakosodott. A többi vámszabad területen mủanyag-, cipö-, fa- és böripari, továbbá vegy-, élelmiszer-, üveg-, gyógyszer- és papíripari termékek gyártása történt (Antalóczy 1999a, 55)

1998-ban a vámszabad területek termelték meg a teljes magyar gépipari export $54 \%$-át. A gépipar vámszabad területi termelésben betöltött jelentőségét jelzik a vámszabad területek külkereskedelmi áruforgalmának adatai is (1. táblázat).

\section{TÁBLÁZAT}

Az ipari vámszabad területek külkereskedelmi forgalmának áruszerkezete, millió Ft (1998)

(Commodity Patterns of Foreign Trade in Industrial Customs-free Zones)

\begin{tabular}{lrrrr}
\hline \multicolumn{1}{c}{ Árufócsoport } & Export & $\begin{array}{c}\text { Ebböl: Európai } \\
\text { Unió }\end{array}$ & Import & $\begin{array}{c}\text { Ebból: Európai } \\
\text { Unió }\end{array}$ \\
\hline Élelmiszerek, ital, dohány & 383 & 383 & 1407 & 7 \\
Nyersanyagok & 1801 & 1763 & 382 & 314 \\
Energiahordozók & 1 & 0 & 1510 & 1507 \\
Feldolgozott termékek & 131025 & 116598 & 254139 & 168957 \\
Gépek és szállítóeszközök & 1644701 & 1426768 & 1132684 & 832615 \\
Összesen & 1777911 & 1545511 & 1390122 & 1003400 \\
\hline
\end{tabular}

Forrás: Külkereskedelmi Statisztikai Évkönyv 1998.

\section{Ipari vámszabad területek Magyarország nyugati határvidékén}

A nyugati határ menti zónában 16 vámszabad terület múködik, melyek 75\%-a (!) gépipari tevékenységet folytat (2. táblázat). 1990-ben a General Motors szentgotthárdi vámszabad területi beruházása volt a nyitánya - s talán a példaképe is - számos nagy gépipari, elektronikai, autóipari beruházásnak, amely szintén vámszabad területre települt. Az ország nyugati határszélén azáltal, hogy megteremtődtek Magyarországon az ipari vámszabad területek létesítésének törvényi feltételei, új, dinamikus ágazatok honosodtak meg a térségben (közúti jármü- és alkatrészgyártás, számítógépgyártás, híradástechnika). A beruházó külföldi érdekeltségü vállalkozások ezáltal az innováció-orientált regionális politika aktív szereplőivé váltak a piacgazdasági átmenet időszakában a nyugati határ menti területeken, de ennek meg- 
valósulásához szükség volt arra, hogy az állam a vizsgált térségek gazdasága számára elérhetővé tegye az újdonsághordozás eszközeit, módszereit, intézményeit.

\section{TÁBLÁZAT}

Ipari vámszabad területek Magyarország nyugati határvidékén (Industrial Customs-free Zones in the Western Borderland of Hungary)

\begin{tabular}{|c|c|c|c|}
\hline & ÜZEMELTETŐ & TELEPHELY & TEVÉKENYSÉG \\
\hline 1) & $\begin{array}{l}\text { OPEL MAGYARORSZÁG } \\
\text { JÁRMÜGYÁRTÓ KFT. }\end{array}$ & Szentgotthárd & Jármủgyártás \\
\hline 2) & VOGEL\&NOOT NIEMEYER KFT. & Szentgotthárd & Mezőgazdasági gépgyártás \\
\hline 3) & STAHLCORD GYÁRTÓ KFT. & Szentgotthárd & $\begin{array}{l}\text { Közúti jármủalkatrészek } \\
\text { gyártása }\end{array}$ \\
\hline 4) & $\begin{array}{l}\text { DELPHI PACKARD ELECTRIC } \\
\text { KÁBELKÖTEGELÖ KFT. }\end{array}$ & Szombathely & $\begin{array}{l}\text { Közúti jármủalkatrészek, } \\
\text { jármüvillamossági készülé- } \\
\text { kek gyártása }\end{array}$ \\
\hline 5) & $\begin{array}{l}\text { PHILIPS MONITORIPAR } \\
\text { MAGYARORSZÁG KFT. }\end{array}$ & Szombathely & $\begin{array}{l}\text { Monitorgyártás és } \\
\text {-összeszerelés }\end{array}$ \\
\hline 6) & LUK SAVARIA KFT. & Szombathely & $\begin{array}{l}\text { Közúti jármüalkatrészek } \\
\text { gyártása }\end{array}$ \\
\hline 7) & DUNAFIL FONO KFT. & Szombathely & Fonalgyártás \\
\hline 8) & KROMBERG ÉS SCHUBERT KFT. & Köszeg & $\begin{array}{l}\text { Villamosipari gépek és } \\
\text { készülékek gyártása }\end{array}$ \\
\hline 9) & $\begin{array}{l}\text { WORLD PROTEIN IPARI ÉS KER. } \\
\text { KFT. }\end{array}$ & Körmend & Tejtermékek gyártása \\
\hline 10) & $\begin{array}{l}\text { SEMPERMED TERMELÉSI ÉS } \\
\text { KERESKEDELMI KFT. }\end{array}$ & Sopron & Gumi- és müanyaggyártás \\
\hline 11) & $\begin{array}{l}\text { SWEDWOOD SOPRON BÚTOR } \\
\text { KFT. }\end{array}$ & Sopron & Bútorgyártás \\
\hline 12) & $\begin{array}{l}\text { VOGEL\&NOOT HÖTECHNIKA } \\
\text { KFT. }\end{array}$ & $\begin{array}{l}\text { Moson- } \\
\text { magyaróvár }\end{array}$ & Lapradiátorok gyártása \\
\hline 13) & $\begin{array}{l}\text { VOGEL\&NOOT MEZŐGÉPGYÁR } \\
\text { KFT. }\end{array}$ & $\begin{array}{l}\text { Moson- } \\
\text { magyaróvár }\end{array}$ & $\begin{array}{l}\text { Fürész-, lemezipar, fémtö- } \\
\text { megcikk-gyártás }\end{array}$ \\
\hline 14) & $\begin{array}{l}\text { VOGEL\&NOOT TECHNOLÓGIAI } \\
\text { KFT. }\end{array}$ & $\begin{array}{l}\text { Moson- } \\
\text { magyaróvár }\end{array}$ & $\begin{array}{l}\text { Hötechnika, fémszerkezet, } \\
\text { kazán, mezögazdasági } \\
\text { gépgyártás }\end{array}$ \\
\hline 15) & $\begin{array}{l}\text { SAMA } \\
\text { JÁRMÜALKATRÉSZGYÁRTÓ BT. }\end{array}$ & Mosonszolnok & $\begin{array}{l}\text { Közúti jármủalkatrészek } \\
\text { gyártása }\end{array}$ \\
\hline 16) & $\begin{array}{l}\text { SAPU IPARI ÉS KERESKEDELMI } \\
\text { BT. }\end{array}$ & Mosonszolnok & $\begin{array}{l}\text { Gépjármüalkatrészek és } \\
\text { tartozékok, kerti kisgépek } \\
\text { gyártása }\end{array}$ \\
\hline
\end{tabular}

Forrás: VPOP; Antalóczy 1999b, 80-85.

A 2. táblázatban felsorolt exportorientált külföldi érdekeltségủ vállalkozások nagy valószínüséggel nem Magyarországra települtek volna, ha nem lett volna megteremtve hazánkban a termelőeszközök, felszerelési és berendezési tárgyak vámfizetés nélküli behozatalának a lehetősége.

A vámpreferenciák nyújtása mellett hangsúlyoznunk kell egy másik közvetett területfejlesztési eszköz szerepét a külföldi múködőtőke-befektetések térségi allokációjában: az adókedvezmények biztosítását. 
A külföldi érdekeltségủ gazdasági társaságok, pl. társaságiadó-kedvezményre 1993. december 31-éig szerezhettek jogot Magyarországon oly módon, hogy eddig az időpontig rendelkeztek az adókedvezmény igénybevételéhez elöírt vagyoni feltétellel (alapítói vagyon nagysága, külföldi részvétel aránya), és megvalósult a termékértékesítés, a különösen fontos tevékenység végzése. Kivételt jelentett az a rendelkezés, amely a jogszerzést a vagyoni feltételek mellett a különösen fontos tevékenység végzése érdekében megkezdett beruházáshoz kötötte. Ez utóbbi esetben is a külföldi részvételủ gazdasági társaságok adókedvezményének jogszerzéséhez több feltételnek kellett teljesülnie. Az adókedvezmény mértéke az első öt évben termékértékesítés esetén a számított adó $60 \%$-a, különösen fontos tevékenység végzése esetén a számított adó $100 \%$-a, a hatodik évtöl a tizedik év végéig pedig különösen fontos tevékenység esetében a számított adó 60\%-a. Az adókedvezményt legfeljebb 2003-ig lehet igénybe venni, az említett időtartamon belüli eltérő mértékkel.

$\mathrm{Az}$ ipari vámszabad területek (vámszabad területi társaságok) önállóan és koncentrált formában gyakorolhatnak hatást egy adott térség fejlódésére, ezáltal a gazdasági, társadalmi térszerkezet alakítására. A nyugati határ menti zónában mindkét formára egyaránt találunk példát. Itt szükséges hangsúlyoznunk az ipari vámszabad területek szoros térbeni kapcsolódását a területfejlesztés sajátos intézményeihez, az ipari parkokhoz. A Szentgotthárdi Ipari Parkban, pl. vámszabad területi formában folytat termelést az Opel Magyarország Jármügyártó Kft., a Vogel\&Noot Niemeyer Kft. és a Stahlcord Kft., a szombathelyi Claudius Ipari és Innovációs Parkban a Delphi Packard Electric Kábelkötegelő Kft., a Philips Monitoripar Magyarország Kft. és a LUK Savaria Kft., továbbá a Sopron Aranyhegyi Ipari Park területén a Swedwood Sopron Bútor Kft. Ezen gazdasági szervezetek egyaránt élni tudtak az ipari vámszabad területen és az ipari parkban való múködés előnyeivel.

\section{Szintézis}

Magyarországon a vámszabad területek müködésének törvényi szabályozása már a rendszerváltás kezdetét megelőzően megtörtént, mely által lehetőség nyílt arra, hogy ezen övezetek a területfejlesztés és a gazdaságpolitika hatékony eszközeivé váljanak a piacgazdaság átmeneti időszakában. Mint gazdaságpolitikai eszközök elősegitették a külföldi befektetők magyarországi beruházásait, az ipar strukturális átalakulását, új ágazatok, technológiák, szakismeretek meghonosítását. Mint területfejlesztési eszközök már az 1990-es évek elején funkcionáltak, tehát időben korábban, mint pl. az ipari parkok, vállalkozási övezetek. Természetesen ez azzal is magyarázható, hogy az állam az ipari parkok kialakításában és müködtetésében közvetlen anyagi támogatást is vállal. Az ipari vámszabad területek térszervező szerepe pozitivan értékelendő: nem jellemző rájuk a főváros-központúság, és bár az ország térszerkezetében az elmúlt évtizedben kialakult kelet-nyugat kettősség itt is kimutatható, ez az ellentét oldódni látszik az autópálya-hálózat fejlesztésével párhuzamosan. 


\section{Jegyzetek}

${ }^{1}$ A vámszabad területek tevékenységük alapján lehetnek kereskedelmi (raktározási) és ipari (termelö) vámszabad területek. Kereskedelmi vámszabad területeken az áruk állagának megörzése, csomagolása, minőségjavítása, ill. az elszállitáshoz szükséges müveletek végezhetök. Létrehozásuk célja a nemzetközi árumozgás meggyorsítása, ezért a legnagyobb kereskedelmi vámszabad területeket olyan helyeken hozzák létre, ahol nagy volumenủ árutranzit bonyolódik (kikötök, repülőterek, vasúti csomópontok). Ipari vámszabad területeken az áruk feldolgozása, kikészítése, összeszerelése, kiszerelése történik általában export célla!. Ezen területek létrehozásánál ugyancsak fontos a jó közlekedés, de a telepítésnél számos más szempontot is figyelembe vesznek mind a befogadó államok, mind a betelepülö vállalkozások.

2 Az 1995. évi vámtörvény kimondja, hogy a Magyar Köztársaság vámterületén székhellyel rendelkezö, gazdasági tevékenységet folytató szervezet legalább $2000 \mathrm{~m}^{2}$ nágyságú, tulajdonában vagy használatában lévő területet nyilváníttathat vámszabad területté. A vámszabad terület a vámterület elkülönített része, amely a vám-, a deviza- és a külkereskedelmi rendelkezések alkalmazása szempontjából külföldnek minösül, azaz a vámszabad területröl a vámterület más részére behozott vámáru olyannak minösül, mintha azt közvetlenül külfóldröl hozták volna be, és a vámterület más részérỏl a vámszabad területre bevitt árut olyannak kell tekinteni, mintha azt külföldre vitték volna.

${ }^{3}$ 1988. évi XXIV. törvény 37. § (1): „Küllföldi által vagy külföldi részvételle! társaság vámszabad területen is alapítható, ilyen társaságban külföldi részesedést szerezhet."

${ }^{4}$ Antalóczy Katalin, a Pénzügykutató Rt. munkatársa, e téma szakértöje tanulmányában azonban rámutat arra, hogy a statisztikai adatok mögött mélyreható folyamatok húzódnak meg: ,....tehát a magyar külkereskedelem vámbelföldi és vámszabad területi sorai között egy belső átrendeződés történik, melyet a statisztikai megfigyelés nem követ nyomon..., továbbá ...a külkereskedelmi statisztika csak az ország határát átlépỏ árumozgásokat veszi számba, nem regisztrálja azonban a vámszabad területek és a vámbelföldiek közötti forgalmat, $\mathrm{s}$ különösen nem követhetö nyomon a vámbelföldi vállalkozások által importált anyagok, alkatrészek esetleges beépülése a vámszabad területi vállalkozások exportjába." $(1999 \mathrm{a}, 59)$

${ }^{5}$ Győr-Moson-Sopron és Vas megye határ menti kistérségei.

\section{Irodalom}

Antalóczy K. (1999a) Vámszabad területek Magyarországon. - Európai Tükör. 5. 47-63. o.

Antalóczy K. (1999b) Vámszabad területek és Magyarország Európai Unióhoz történö csatlakozása. Európai Tükör Mühelytanulmányok. 64. 41-88. o.

Bartke I. (szerk.) (1995) Területfejlesztés. Egyetemi jegyzet. Budapest, ELTE Eötvős Kiadó.

Béda F. (szerk.) (1993) Vámszabad terillet. Oktatási Segédanyag. Budapest, CO-NEX-TRAINING Bt., Szakmai Fórum.

Buzási T. (1999) A vámszabad területek jövője. - VÁM-ZOLL. 4. 15. o.

Külkereskedelmi Statisztikai Évkönyv 1998. (1999) Budapest, KSH.

Regös ZS. (1999) Befektetőcsalogató zónák. - Népszava. nov. 6. 1. o., 5. o.

Ruttkay É. (1994) Gazdasági zónák. - Comitatus. július. 27. o.

\section{CUSTOMS-FREE ZONES AND THEIR SPACE-ORGANISING ROLE IN HUNGARY}

\section{EDINA VOLTER}

In Hungary the commercial and industrial customs-free zones have already been operating successfully for more than two decades, as means of regional development and economic policy. The commercial customs-free zones have been functioning as means of economic policy especially in the 1980 s, and have gained large-scale convertible currency for the 
national economy. The industrial customs-free zones, as means of economic policy have been promoted by foreign capital investments, the structural transformation of the industry and the naturalization of new branches in Hungary. In the period of ecomomic transition the industrial customs-free zone, as a means of regional development, has operated most efficiently in the Western and Central Transdanubian Regions. 